\title{
Accuracy of 18-FDG PET/CT in the Differential Diagnosis of Malignant and Benign Pleural Diseases
}

\author{
Kenan C. CEYLAN ${ }^{1}$, Deniz AKPINAR ${ }^{1}$, Seyda O. KAYA ${ }^{1}$, Hakan KOPARAL ${ }^{2}$, Ali Kadri CIRAK ${ }^{3}$ \\ ${ }^{1}$ Dr. Suat Seren Chest Diseases and Thoracic Surgery Training Hospital, 2nd Thoracic Surgery Clinic, Izmir \\ ${ }^{2}$ Dr. Suat Seren Chest Diseases and Thoracic Surgery Training Hospital, Department of Nucleer Medicine, Izmir \\ ${ }^{3}$ Dr. Suat Seren Chest Diseases and Thoracic Surgery Training Hospital, Chest Diseases Clinic, Izmir, TURKEY
}

\begin{abstract}
Integrated whole-body 18-fluorodeoxyglucose positron emission tomography-computed tomography (PET/CT) is a non-invasive imaging technique for identifying several types of malignant diseases. We evaluated the role of PET/CT in distinguishing malignant from benign pleural diseases. Thirty patients, who had pleural abnormalities on computed tomography (CT), such as thickening, fluid with suspicion of malignant pleural mesothelioma or any other malignancy underwent PET/CT. Maximum standardized uptake values (SUVmax) were calculated separately for pleural thickening and pleural fluid and compared with pathological results obtained by video thoracoscopy. Twenty-two patients with pleural thickening and 25 patients with pleural fluid were assessed with regard to the accuracy of PET/CT. The overall sensitivity, specificity, positive predictive value (PPV), negative predictive value (NPV), and accuracy of PET/CT was $81.8 \%, 54.5 \%, 64.3 \%, 75 \%$, and $68.2 \%$ for pleural thickening and it was $100 \%, 56.5 \%, 41.1 \%, 100 \%$, and $60 \%$ for patients with pleural fluid. When the pleural thickening was evaluated, the SUVmax values were higher in the malignant pleural diseases than in the benign pleural diseases but the difference was not statistically significantly $(p=0.063)$. When the pleural fluid was evaluated, the SUVmax values were also higher in the malignant pleural diseases than in the benign pleural diseases and the difference was statistically significantly $(p=0.03)$. The accuracy of PET/CT for detecting malignant pleural fluids was high. However, PET/CT was not adequate to make the differential diagnosis of pleural malignancies especially in case of pleural thickening because of its relatively low sensitivity,specificity,PPV, and NPV. A tissue biopsy is necessary to determine the diagnosis.
\end{abstract}

Keywords: 18-fluorodeoxiglucose-positron emission tomography, Pleural Disease

ÖZET

Malign ve Benign Plevral Hastalıkların Ayırıcı Tanısında 18-FDG PET/BT'nin Etkinliği

Tüm vücut 18-florodeoksiglukoz pozitron emisyon tomografi /bilgisayarlı tomografisi (PET / BT) birçok malign hastalığın tanısında kullanılan non-invaziv bir hibrid görüntüleme tekniğidir. Çalışmamızda malign ve benign plevral hastalıkların ayıııcı tanısında PET / BT'nin etkinliği değerlendirildi. Bilgisayarlı tomografide malign plevral mezotelyoma ve diğer malignite şüphesi oluşturan plevral kalınlaşma veya plevral SIVISI saptanan 30 hastaya PET / BT uygulandı. SUVmax değerleri plevral kalınlaşma ve plevral sIVı için ayrı ayrı hesaplanarak video torakoskopi ile elde edilen patoloji sonuçları ile karşılaştııılı. Plevral kalınlaşması olan 22 hasta ve plevral sıvısı olan 25 hasta PET / BT etkinliği açısından değerlendirildi. Plevral kalınlaşma için duyarlıık, özgüllük, pozitif prediktif değer (PPV), negatif prediktif değeri (NPD) ve PET / BT'nin etkinlik oranı sırasıyla \%81.8, \%54.5, \%64.3, \%75 ve \%68.2, plevra sıvı için sırasılyla \%100, \%56.5, \%41.1, \%100 ve \%60 idi. Plevral kalınlaşma için bakıldığında SUVmax değerleri malign hastalarda daha yüksek olmakla beraber aradaki fark istatistiksel olarak anlamlı değildi $(p=0.063)$. 
Plevral Sıvı için bakıldığında SUVmax değerleri malign hastalarda daha yüksek bulundu ve aradaki fark istatistiksel olarak anlamIı bulundu ( $p=0.03)$. Malign plevral sıvıları saptamada PET / BT etkinliği oldukça yüksektir ancak, düşük duyarlılı, özgüllük, PPV ve NPV değerleri özellikle plevral kalınlaşma durumunda plevral malignitelerin ayırıcı tanısı için yeterli değildir. Kesin tanının belirlenmesinde doku biyopsisi mutlak surette gereklidir.

Anahtar Kelimeler: 18-florodeoxiglukoz-positron emisyon tomografi, Plevral Hastalıklar

\section{INTRODUCTION}

Pleural diseases appear as pleural thickening or pleural fluid in the thorax on computed tomography (CT). Pleural diseases, such as infectious pleuritis, pleural fibrosis, malignant pleural mesothelioma (MPM), and lung cancer metastasis, result in pleural effusions and can look similar on CT. When such findings are identified on a CT scan, it is difficult to distinguish whether the disease is malignant or benign. Although lung cancer is the most common cause of pleural effusion, MPM, breast cancer, lymphoma and gastrointestinal tumours can also involve the pleura and cause pleural effusion. Pleural diseases can be diagnosed by pleural biopsy. In some cases, biopsy results are inconclusive; thus, video-assisted thoracoscopic surgery (VATS) or a thoracotomy may be required.

MPM is often seen as pleural thickening or as pleural fluid. Some regions of our country have an increased risk for MPM, a rare, yet aggressive, tumour, which usually has a poor prognosis. Rapidly distinguishing between benign and malignant pleural diseases is important, because a few selected patients may benefit from chemotherapy or trimodal treatment. ${ }^{1}$

Whole-body 18-fluorodeoxiglucose-positron emission tomography (FDG-PET) is a non-invasive imaging technique and diagnostic tool for several types of malignant disease (2). Recent studies have shown that the sensitivity of FDG-PET is within the range $93-96 \%$ for diagnosing malignant pleural diseases. . $3,4^{3,4}$

We compared PET/CT results with pathological results for diagnoses of pleural thickening and pleural fluid.

\section{PATIENTS AND METHODS}

Thirty patients who had pleural abnormalities, such as thickening or fluid with suspicion of MPM or any other malignancy on CT scans, underwent
PET/CT between April 2007 and March 2010. All patients were investigated by chest physicians, and a blind-needle pleural biopsy was performed. Although a visual analysis by CT, PET/CT, and a blind-needle biopsy was used to distinguish benign from malignant pleural disease, the patients were referred to our clinic for invasive surgical procedures to analyse the accuracy of PET/CT. VATS was considered initially, because the diagnostic value of VATS is greater in diagnosing pleural diseases. All patients were evaluated with a history, physical examination, whole blood analyses, a pulmonary function test, chest radiography, chest $\mathrm{CT}$, and bronchoscopy. Chemical and cytological analyses of the pleural fluid were conducted in all patients. Eligibility criteria for this study were pleural thickening or pleural fluid on chest CT, suspicion of malignancy, and medical fitness for surgical diagnostic procedures (video thoracoscopy or thoracotomy). CT findings, such as pleural thickening and pleural fluid were evaluated in correlation with $\mathrm{PET} / \mathrm{CT}$ and pathological reports independently. The same patients were analysed for both CT findings to evaluate the accuracy of PET/CT for both pleural thickening and fluid.

This study was approved by the medical ethics committee of Dr. Suat Seren Chest Disease and Chest Surgery Teaching Hospital and was designed prospectively.

\section{PET/CT}

PET/CT was performed in our hospital, using a dedicated full-ring scanner (ECAT ACCELL; Siemens Medical Systems, Biograph Duo 2 Slice CT, Erlangen Germany). Plasma glucose values were < $200 \mathrm{mg} / \mathrm{dL}$. FDG activity of 370-555 MBq was injected intravenously, depending on the patient's weight. Attenuation-corrected whole-body PET/CT scans in three-dimensional mode were acquired 60 min after FDG administration, using a machine equipped with lutetium oxyorthosilicate crystals 
and a $162 \mathrm{~mm}$ axial field of view. Scans were performed from the inferior pelvis to the vertex.

To minimize variability in the standardized uptake value (SUV) due to body composition, the SUV was calculated using lean body mass. Malignant or benign separation was performed according to the interpretations of nuclear medicine specialists. They evaluated the PET/CT results as malignant when the SUVmax value was $>2.5$, which was considered a positive result; if they evaluated it as benign diseases (SUVmax $\leq 2.5$ ) it was considered a negative result. The SUVmax values for pleural thickening and pleural fluid were calculated for each PET/CT finding separately and compared with appropriate pathological results.

\section{Operation and Pathological Examination}

We performed VATS, because a pleural biopsy had already been performed in all patients. VATS was the first option, but a mini thoracotomy was performed in two patients because of strict adherence to the overlying parietal pleura. We used a double-lumen endotracheal tube for intubation. First, the pleural fluid was aspirated, and then multiple biopsies were obtained from different locations in the pleura.

Pathological specimens were sampled from visceral pleura, parietal pleura, and pleural fluid. Pathological examination methods included cytology, histology and, if necessary, immunohistochemistry. Haematoxylin and eosin staining was used for all patient specimens. To verify the differential diagnosis of malignancy, pancytokeratin, vimentin, carcinoembryonic antigen, Tag-72, and calretinin were analysed by immunohistochemistry.
Statistical Analysis: Sensitivity, specificity, positive predictive value (PPV), negative predictive value (NPV), and PET/CT accuracy were calculated separately for pleural thickening and pleural fluid. A receiver operating characteristic (ROC) analysis was used. A $p$ value $<0.05$ was considered to indicate statistical significance.

\section{RESULTS}

Thirty patients were included; 19 males and 11 females, with a mean age of 52.5 (range, 32-71) years. Twenty-two of 30 patients (73.3\%) had pleural thickening (5 patients had only pleural thickening, 17 patients had pleural thickening with pleural fluid) on CT scans. These 22 patients were examined for PET/CT accuracy of pleural thickening. Twenty-five of the 30 patients $(83.3 \%)$ had pleural fluid ( 8 patients had only pleural fluid and 17 patients had pleural thickening with pleural fluid) on CT scans. These 25 patients were examined for PET/CT accuracy of pleural fluid on the basis of pathological examination.

Twenty-eight VATS and two limited thoracotomies were performed. No operative or postoperative mortality was noted. One case of prolonged air leak and one of atrial fibrillation were seen as postoperative morbidities.

\section{Pleural Thickening}

Pleural thickening was observed in 22 patients on CT scans. In 17 patients, pleural fluid and thickening occurred together. By PET/CT, 14 malignant (SUVmax > 2.5), eight benign (SUVmax $\leq 2.5)$ diseases were detected in patients with pleural thickening. The mean SUVmax was 6.7 (range, 2.6-22.0)

\begin{tabular}{|c|c|c|c|c|c|c|c|c|c|}
\hline \multirow[t]{2}{*}{ CT Findings } & \multicolumn{2}{|c|}{ PET Findings } & \multicolumn{2}{|c|}{ Pathological Results } & \multirow[t]{2}{*}{ Sensitivity } & \multirow[t]{2}{*}{ Specificity } & \multirow[t]{2}{*}{ PPV } & \multirow[t]{2}{*}{ NPV } & \multirow[t]{2}{*}{ Accuracy } \\
\hline & Negative & Positive & Benign & Malignant & & & & & \\
\hline $\begin{array}{l}\text { Pleural Thickening } \\
(\mathrm{n}=22)\end{array}$ & 8 & 14 & 11 & 11 & 81.8 & 54.5 & 64.3 & 75 & 68.2 \\
\hline $\begin{array}{l}\text { Pleural Fluid } \\
(n=25)\end{array}$ & 18 & 7 & 8 & 17 & 100 & 56.5 & 41.1 & 100 & 60 \\
\hline
\end{tabular}




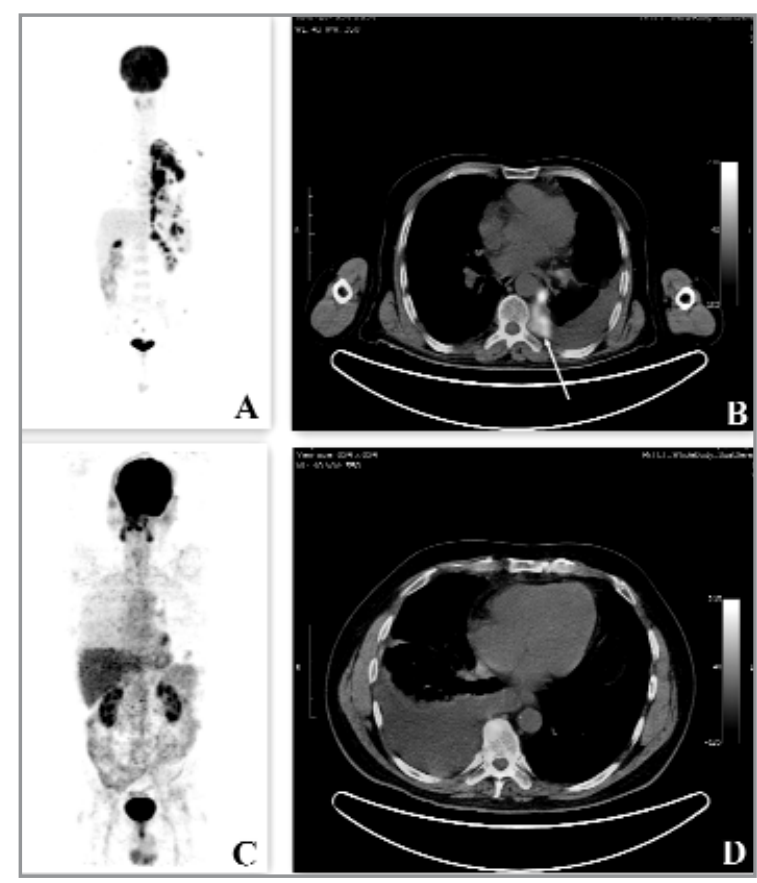

Figure 1A, 1B. Positive PET/CT with malignant pleural fluid

Figure 1C, 1D. Negative PET/CT with benign pleural fluid

for PET/CT-positive patients and 1.57 (range, 0.0-2.4) for PET/CT-negative patients, but this difference was not statistically significant $(\mathrm{p}=0.063)$. The pathological diagnoses in the 14 PET/CT-positive patients were nine malignant (2 MPM, 5 adenocarcinoma metastases, and 2 breast cancer metastases) and five benign diseases (4 non-specific pleuritis and 1 case of tuberculosis). The pathological diagnoses in the eight PET/CT-negative patients were six benign diseases ( 5 non-specific pleuritis and 1 case of tuberculosis) and two with MPM. In the false-negative results observed in patients with MPM, the histological subtype was epithelioid MPM for all, and the SUVmax values were between 0 and 2.4. In the false-positive patients with nonspecific pleuritis, the SUVmax values were between 2.7 and 12.0 or 4.2 for tuberculosis. The overall sensitivity, specificity, PPV, NPV, and accuracy for PET/CT was $81.8 \%, 54.5 \%, 64.3 \%, 75 \%$, and $68.2 \%$ for pleural thickening (Table 1 ).

\section{Pleural Fluid}

Pleural effusion was observed in 25 patients. The SUVmax values were calculated for pleural fluid. Seven patients had positive PET/CT results with

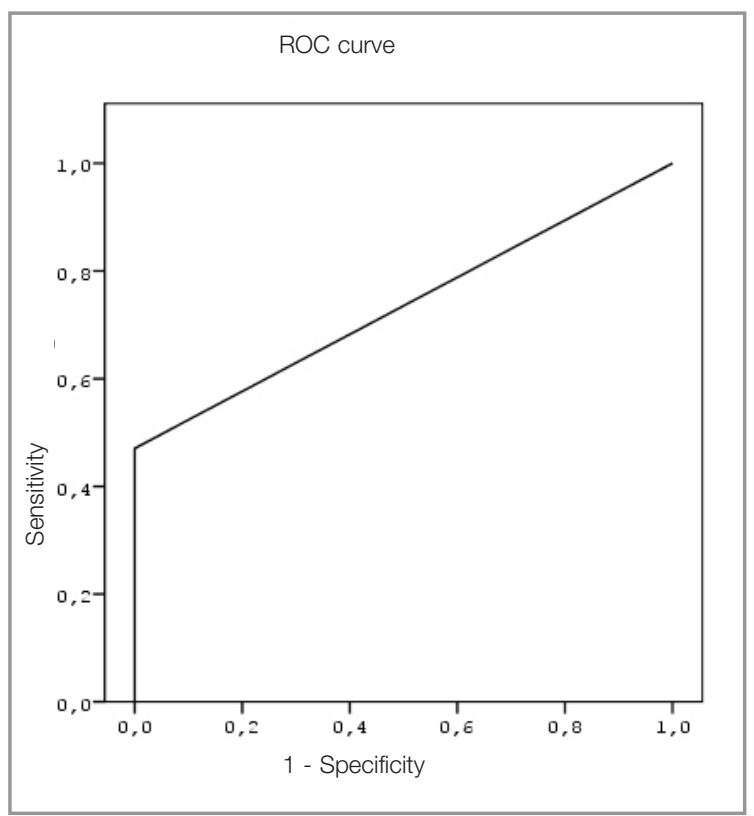

Figure 2. ROC analysis, the area under the curve for the pleural fluid SUVmax level was $0.735(p=0.03)$

SUV max values of 4.3-11.2. These seven patients were diagnosed pathologically with malignant pleural fluid: two metastatic adenocarcinomas, two MPMs, two adenocarcinomas of the lung and one breast cancer metastasis (Figure 1A, 1B). The $\mathrm{PET} / \mathrm{CT}$ results were negative in 18 patients with pleural fluid (Figure 1C, 1D). The final pathological results were reported as ten patients with malignant pleural fluid (5 MPM, 4 adenocarcinoma metastases, and 1 breast carcinoma metastasis) and eight with benign pleural fluid (7 with non-specific pleuritis and 1 with tuberculosis). The mean SUVmax value was 7.58 (range, 4.3-11.2) for the PET/CT-positive patients and 0.2 (range, 0.0-2.4) for the PET/CT-negative patients. In the ROC analysis, the area under the curve for the pleural fluid SUVmax level was 0.735 ( $\mathrm{p}=0.03$; Figure 2). The overall sensitivity, specificity, PPV, NPV, and accuracy of PET/CT were 100\%, 56.5\%, $41.1 \%$, $100 \%$, and $60 \%$ for patients with pleural fluid (Table 1$)$.

\section{DISCUSSION}

Pleural thickening or pleural fluid can occur in both benign and malignant diseases. The differential di- 
agnosis between benign and malignant pleural diseases is crucial because the survival after acquiring a malignant pleural disease is poor, and treatment strategies differ. Some reports have demonstrated that PET/CT is highly accurate in the differential diagnosis of pleural disease and is superior to CT. ${ }^{5,67}$ Additionally, some authors have reported that PET/CT is highly accurate for staging patients with MPM. ${ }^{8,9,10}$ Many studies have evaluated the diagnostic value of PET/CT in malignant pleural diseases, such as lung cancer or MPM ${ }^{11,12,13,14}$, but few have evaluated the accuracy of PET/CT in distinguishing malignant from benign disease.

Schaffler et al. reported that the accuracy of PET for detecting pleural malignancies in non-small cell lung cancer is $80 \%$ with $100 \%$ sensitivity. ${ }^{15}$ In Flores et al., 63 patients with proven MPM underwent PET with a 57\% PPV and a $63 \%$ NPV. They reported that negative PET scans do not rule out the presence of MPM (16). Otsuka et al. reported that the utility of PET/CT was limited for evaluating primary tumour extension and nodal status, but that PET/CT was useful for detecting distant metastases. ${ }^{17}$ Additionally, if tumour implants are smaller than $5 \mathrm{~mm}$, they may not be detected by conventional imaging. ${ }^{18}$ In our study, the overall sensitivity, specificity, PPV, NPV, and accuracy of PET/CT was $81.8 \%, 54.5 \%, 64.3 \%, 75 \%$, and $68.2 \%$ for patients with pleural thickening and $100 \%, 56.5 \%$, $41.1 \%, 100 \%$, and $60 \%$ for patients with pleural fluid, respectively.

Two patients were diagnosed with epithelioid-type MPM with false-negative PET findings in the pleural thickening group, and five patients were diagnosed with epithelioid-type MPM in the pleural fluid group. The SUVmax value was between 0 and 2.4 in these seven patients. Generally, SUVmax values are lower than other types of lung cancer with lower tumour metabolism, such as in epithelioidtype MPM or adenocarcinoma, in contrast, infectious or granulomatosus diseases can cause false-positive results without malignancy on PET. ${ }^{19,20,21}$ Four patients with a false-positive PET result were diagnosed with infectious pleuritis, and one was diagnosed with tuberculosis in the pleural thickening group. We think that the false-negative PET/CT results are due to the low tumour metabolism of MPM, and that the false-positive PET/CT results are due to the infectious process.

Kramer et al. reported that patients with pleural thickening may be followed using CT alone, rather than pathological diagnostic procedures, due to the high NPV percentage of PET (92\%) and that positive PET findings should always lead to a tissue verification procedure. ${ }^{2}$ The NPV and sensitivity values we found were not high enough to follow-up patients with pleural thickening using PET/CT. Zahid et al. investigated the best method for diagnosing and staging MPM.22 They searched the literature and found 61 studies. They concluded that pleural biopsy provided the most accurate definitive diagnosis for MPM. We share the same perspective and believe that a tissue biopsy is necessary to determine the diagnosis for patients with PET/CT-negative or -positive pleural diseases. A limitation of our study was the relatively small number of patients.

\section{CONCLUSION}

The accuracy of PET/CT for detecting malignant pleural fluid is high. However, PET/CT is not adequate to identify pleural malignancies especially for the patients with pleural thickening because of its low sensitivity, specificity, PPV, and NPV. Thus, a tissue biopsy is also necessary to determine the diagnosis for patients with PET-negative or -positive pleural thickening.

\section{REFERENCES}

1. Sugarbaker DJ, Flores RM, Jaklitsch MT, et al. Resection margins, extrapleural nodal status, and cell type determine postoperative long-term survival in trimodality therapy of malignant pleural mesothelioma: results in 183 patients. J Thorac Cardiovasc Surg 117: 54-63, 1999.

2. Kramer H, Pieterman RM, Slebos D, et al. PET for the Evaluation of Pleural Thickening Observed on CT. J Nucl Med 6: 995-998, 2004.

3. Bruno A, Spini A, Zangheri B. Characterization of pleural mesothelioma: Diagnostic and prognostic value of FDG-PET. J Nucl Med 48: 356, 2007.

4. Yamamoto $Y$, Nishiyama $Y$, Gotoh M, et al. FDG PET in the evaluation of malignant pleural mesothelioma. J Nucl Med 47: 475, 2006. 
5. Caretta A, Landoni C, Melloni G, et al. 18-FDG PET in Evaluation of Malignant Pleural Diseases. Eur J Cardiothorac Surg 17: 377-383, 2000.

6. Orki A, Akın O, Tascı E, et al. The role of positron emission tomography/computed tomography in the diagnosis of pleural diseases. Thorac Cardiovasc Surg 57: 217-221, 2009.

7. Duysinx B, Corhay JL, Nguyen D, Louis R. How to explore a pleural diseases? Rey Med Liege 63: 615623, 2008.

8. Gill RR. Imaging of mesothelioma. Recent Results Cancer Res 189: 27-43, 2011.

9. Scheider DB, Clary-Macy C, Challa S, et al. Positron Emission Tomography with f18-fluorodeoxyglucose in the staging and preoperative evaluation of malignant pleural mesothelioma. J Thorac Cardiovasc Surg 120: 128-133, 2000.

10. Erasmus J, Truong MT, Smythe WR, et al. Integrated computed tomography-positron emission tomography in patients with potentially resectable malignant pleural mesothelioma:Staging implications. J Thorac Cardiovasc Surg 129: 1364-1370, 2005.

11. Kim BS, Kim IJ, Kim SJ, Kim K. Predictive value of F18 FDG PET/CT for malignant pleural effusion in nonsmall cell lung cancer patients. Onkologie 34: 298303, 2011.

12. Alkhawaldeh K, Biersack HJ, Henke A, Ezziddin S. Impact daul-time-point F-18 FDG PET/CT in assessment of pleural effusions in patients non-small cell lung cancer. Clin Nuc Med 36: 423-428, 2011.

13. Gupta NC, Rogers JS, Graeber GM, et al. Clinical of F18 flourodeoxyglucose positron emission tomography imaging in patients with lung cancer and suspected malign pleural effusion. Chest 122: 1918-1924, 2002.

14. Erasmus JJ, Mcadams HP, Rossi SE, Goodman PC, Coleman RE, Patz EF. FDG PET of pleural effusions in patients with non small cell lung cancer. AJR Am J Roentgenol 175: 245-249, 2000.

15. Schaffler GJ, Wolf G, Schoellnast $H$, Groell R, et al. Non-Small Cell Lung Cancer: Evaluation of Pleural Abnormalities on CT Scans with FDG PET. Radiology 231: 858-865, 2004.

16. Flores RM, Akhurst T, Gonen M, et al. Positron emission tomography defines metastatic disease but not locoregional disease in patient with malignant pleural mesothelioma. J Thorac Cardiovasc Surg 126: 11-15, 2003.
17. Otsuka H, Terazawa K, Morita N, et al. Is FDG-PET/CT useful for managing malignant pleural mesothelioma? J Med Invest 56: 16-20, 2009.

18. Asad S, Aquino SL, Piyavisetpat N, Fischman AJ. False-positive FDG positron emission tomography uptake in nonmalignant chest abnormalities. Am J Roentgenol 182: 983-989, 2004.

19. Melek H, Günlüoğlu MZ, Demir A, et al. Role of Positron Emission Tomography in Mediastinal Lymphatic Staging of Non-Small Cell Lung Cancer. Eur J Cardiothorac Surg 33: 294-299, 2008.

20. Al-Sarraf N, Gately K, Lucey J, et al. Lymph node staging by means of positron emission tomography is less accurate in non-small cell lung cancer patients with enlarged lymph nodes: Analyses of 1145 lymph nodes. Lung Cancer 60: 62-68, 2008.

21. Bryant AS, Cerfolio RJ, Klemm KM, Ojha B. Maximum Standart Uptake of Mediastinal Lymph Nodes on Integrated FDG-PET-CT Predicts Pathology in Patients with Non-Small Cell Lung Cancer. Ann Thorac Surg 82: 417-423, 2006.

22. Zahid I, Routledge T, Bille A, Scarci M. What is the best treatment for malignant pleural effusions? Interact Cardiovasc Thorac Surg 12: 254-259, 2011.

\section{Correspondence}

Dr. Kenan Can CEYLAN

Dr. Suat Seren Göğüs Hastalıkları ve Göğüs Cerrahisi

Eğitim ve Araştırma Hastanesi

Göğüs Cerrahisi Kliniği

Yenişehir, IZMIR / TURKEY

Tel: (+90.232) 4333333

Fax no: (+90.232) 4587262

e-mail: kcanceylan@gmail.com 